\title{
Olfactory Groove Schwannoma-A Case Report and Literature Review
}

\section{Schwannoma de Goteira Olfatória-Relato de Caso e Revisão de Literatura}

\author{
Marcelo Pedrotti De Cesaro ${ }^{1}$ Moisés Augusto Araújo ${ }^{2}$ Fernada de Carli ${ }^{1}$ Gregori Manfroi ${ }^{1}$ \\ Daniela Schwingel ${ }^{3,4}$ Paulo Moacir Mesquita Filho $2,3,5$
}

${ }^{1}$ Faculty of Medicine, Universidade de Passo Fundo, Passo Fundo, RS, Brazil

2 Department of Neurosurgery, Hospital da Cidade de Passo Fundo, Passo Fundo, RS, Brazil

${ }^{3}$ School of Medicine, Instituto Meridional, Passo Fundo, RS, Brazil

${ }^{4}$ Instituto de Patologia de Passo Fundo, Passo Fundo, RS, Brazil

${ }^{5}$ Neurology and Neurosurgery Service, Passo Fundo, RS, Brazil

\begin{abstract}
Address for correspondence Marcelo Pedrotti De Cesaro, Faculdade de Medicina, Universidade de Passo Fundo, Rua Teixeira Soares 24, Apto. 301, 99010-080, Passo Fundo, RS, Brazil

(e-mail: mpedrottidecesaro@gmail.com).
\end{abstract}

Arq Bras Neurocir 2018;37:223-226.

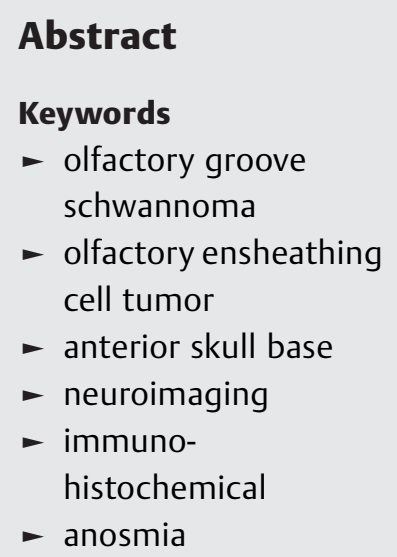

\section{Resumo}

Palavras-chave

- schwannoma da goteira olfatória

- tumor de células envoltórias olfativas

- base do crânio anterior

- neuroimagem

- imunohistoquímica

- anosmia
Olfactory groove schwannomas (OGSs) are rare benign tumors of the anterior skull base region. Considering the lack of Schwann cells in the optic and olfactory nerves, their origin remains enigmatic. Despite the precursor cell, total resection of the lesion is curative, as long as the histopathological features of the tumor are compatible with schwannoma. We report the case of a 32-year-old woman, addicted to crack, who was brought to the hospital presenting with cognitive dysfunction after being physically assaulted, whose neuroimaging revealed a large extra-axial mass in the subfrontal sagittal region. The presentation, immunohistochemical markers and histogenesis are discussed in the present study, along with a literature review.

O schwannoma da goteira olfatória (SGO) é um tipo de tumor raro da região anterior da base do crânio. Devido à inexistência de células de Schwann nos nervos óptico e olfatório, a origem desses tumores permanece enigmática. Independentemente da célula precursora, a ressecção total do tumor demonstrou ser curativa, desde que o tumor apresente características histopatológicas condizentes com schwannoma. Relatamos aqui o caso de uma mulher de 32 anos, dependente de crack, que foi trazida ao hospital apresentando disfunção cognitiva após sofrer agressão física. A neuroimagem revelou uma grande massa extra-axial se estendendo desde a goteira olfatória até a região entre os hemisférios frontais. A paciente foi submetida a tratamento cirúrgico, e o tumor foi removido completamente. A apresentação clínica, marcadores imunohistoquímicos e a histopatogênese são discutidos no presente estudo, juntamente com uma revisão da literatura. received

February 1, 2018

accepted

June 8, 2018

published online

August 20, 2018
DOI https://doi.org/

10.1055/s-0038-1668173. ISSN 0103-5355.
Copyright $\odot 2018$ by Thieme Revinter

Publicações Ltda, Rio de Janeiro, Brazil
License terms

(요 (1) $\Theta$ 


\section{Introduction}

Accounting for $\sim 8 \%$ of the intracranial tumors, schwannomas are slow-growing, benign tumors ${ }^{1-3}$ that emerge from the nerve sheath. ${ }^{4}$ The majority of the cases are located in the vestibular portion of the 8th cranial nerve, and less commonly on the 5th, the 9th, the 10th and the 12th cranial nerves. ${ }^{1,3}$ Extremely rare and with an enigmatic origin, schwannomas are found in the anterior cranial fossa, specially in the olfactory groove. $^{2}$ We report the case of an olfactory groove schwannoma (OGS) along with a brief literature review of the pathogenesis and origin of the schwanommas.

\section{Case Report}

A 32-year-old woman, heavily addicted to crack, was brought to the emergency department after being physically assaulted. She presented with altered mental status, saying inappropriate words (Glasgow coma score $[\mathrm{GCS}]=13$ ) and diffuse body hematomas, mainly in the dorsal region. No focal neurological deficit was detected.

A computed tomography (CT) brain scan revealed an extra-axial hyperdense contrast-enhancing lesion in the subfrontal sagittal region, measuring $5.0 \times 4.8 \times 4.5 \mathrm{~cm}$, which caused mass effect in the frontal lobes and displaced the cribriform plate downwards.

It was unlikely that the CT findings were related to the psychological disturbance of the patient, since 24 hours after being admitted she recovered the mental status, but complained of anosmia. Confusion and disorientation could have been caused either by the effects of crack or the traumatic brain injury (TBI), with the association of both also being a possibility regarding the peculiarity of the patient.

On further examination, a magnetic resonance imaging (MRI) exam evidenced a large mass arising from the skull base, protruding into the nasal cavity and expanding between the frontal lobes, displacing them laterally. AT1-weighted MRI with gadolinium enhancement showed involvement of the olfactory groove and irregular contrast distribution inside the tumor. A T2-weighted MRI exam evidenced the solid mass without invasion of the frontal lobes, and the fluid attenuation inversion recovery (FLAIR) sequence demonstrated a mild perilesional edema, despite the tumor volume ( - Fig. 1A-E).

The patient was submitted to surgery, through a bifrontal craniotomy, ligation of the anterior superior sagittal sinus and inter-hemispheric approach. The tumor was fibroelastic, brownish and well-vascularized, attached to the olfactory groove. The olfactory bulb was not identified during resection,
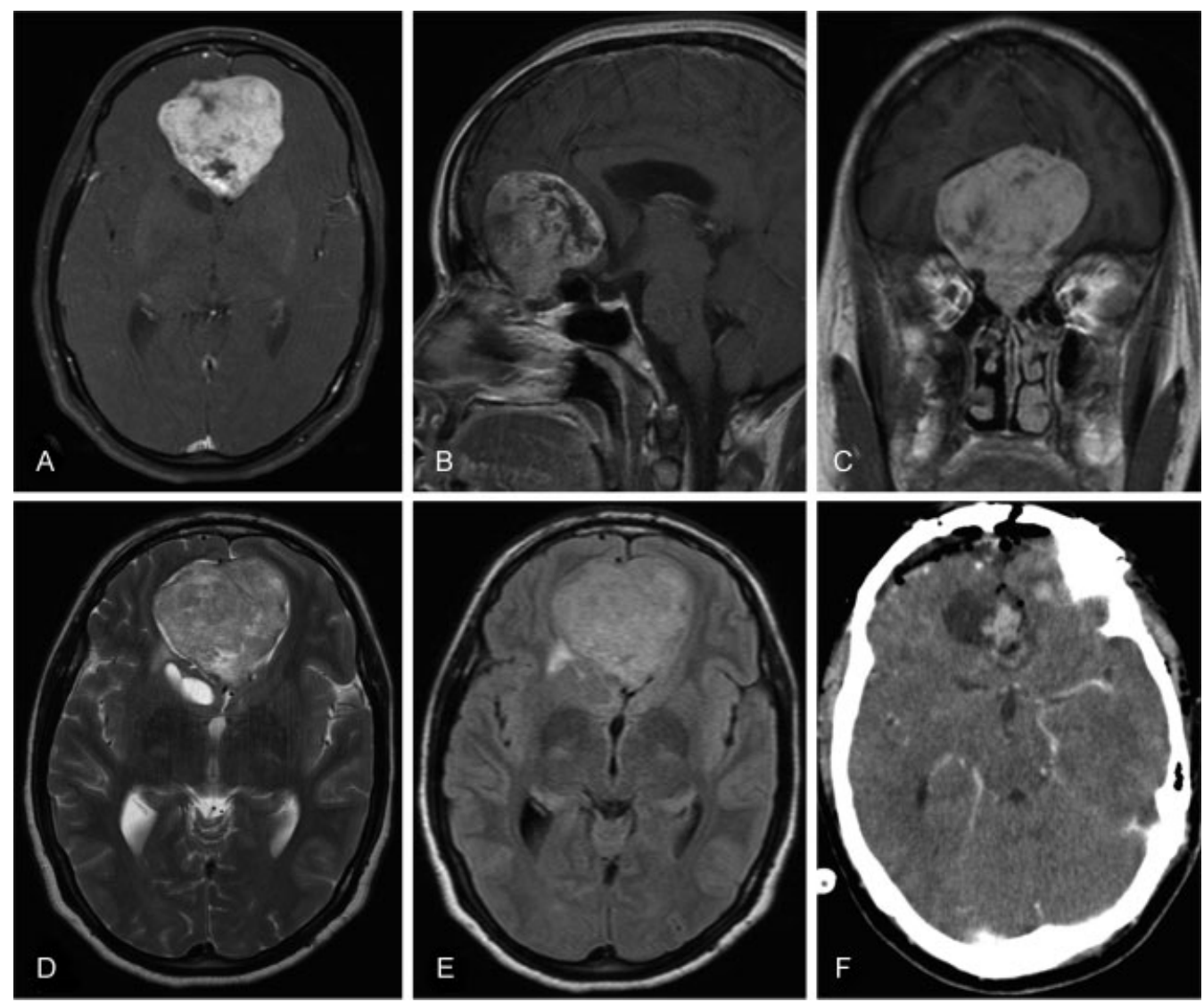

Fig. 1 (A) Axial T1-weighted MRI with gadolinium enhancement, evidencing a huge mass, with irregular contrast enhancement between the frontal lobes displacing them. (B) Sagittal T1-weighted MRI with gadolinium enhancement, showing the involvement of the olfactory groove by the tumor with displacement of cribriform plate downwards. (C) Coronal T1-weighted MRI with gadolinium enhancement, also showing the protrusion of the mass through the nasal cavity. (D) Axial T2-weighted MRI, evidencing the solid and extra-axial mass, between the frontal lobes, without invading them. (E) Axial FLAIR MRI, showing only mild edema, besides the great diameter of the lesion. (F) Axial postoperative CT scan, evidencing total resection of the tumor. Abbreviations: $\mathrm{CT}$, computed tomography; FLAIR, fluid attenuation inversion recovery; MRI, magnetic resonance imaging. 
and the tumor was completely excised. An immediate postoperative CT scan confirmed the total removal of the tumor (-Fig. 1F).

The resected tissue displayed all the histopathological schwannoma hallmarks, evidenced by its two-phase aspect, composed of alternating cellular and hypocellular areas, called Antoni A and Antoni B areas, respectively. Cells with twisted or wavy nuclei and indistinct cytoplasmic borders. Palisading nuclei that form compact rows surrounding fibrillary pink cytoplasm, called Verocay bodies. The cells had pleomorphic and hyperchromatic nuclei, but mitotic figures were not evident (-Fig. 2 A, B). An immunohistochemical (IHC) staining test displayed positive tumor cells for S-100 protein, but negative staining for epithelial membrane antigen (EMA) ( $\mathbf{- F i g . ~ 2 C ) . ~}$

The postoperative period was uneventful, despite one episode of complex partial seizure, and the preexisting anosmia. After 1 year, the patient remains free of disease and had no other neurological deficits.

\section{Discussion}

To date, only 56 cases of OGS have been reported in the literature. ${ }^{5}$ The ages of the affected patients vary, mainly, between 20 and 50 years old. ${ }^{6}$ The clinical presentation of OGSs has a diverse range, including asymptomatic, anosmia/ hyposmia (the most common finding), seizures, headache, ${ }^{1,6}$ visual deficits, cognitive disturbances, rhinorrhea, ${ }^{1}$ motor and sensory dysfunction, and intracranial hypertension. ${ }^{6}$

Aware that optic and olfactory nerves, as part of the central nervous system (CNS), ${ }^{7}$ do not have a Schwann cell sheath, and that intracranial schwannomas unrelated to cranial nerve occur mainly in the midline of the anterior cranial fossa, there is a divergence concerning the origin of OGSs and whether they are primarily intra or extra-axial lesions. ${ }^{1,3,6}$ Despite several hypothesis concerning their probable origin, the true original site of OGSs remains controversial. ${ }^{3,5}$

Developmental theories suggest an intraparenchymal origin, ${ }^{1}$ either by transformation of a mesenchymal pial cell into ectodermal Schwann cells or by the migration of neural crest cells within the CNS. ${ }^{6}$ Still, there is a theory suggesting the origin of Schwann cells from multipotent mesenchymal cells after an injury. ${ }^{2}$

Non-developmental hypotheses believe that intracranial schwannomas are extra-axial lesions arising from adjacent structures that present Schwann cells, namely, the meningeal branches of the trigeminal, the anterior ethmoidal nerves and the nerve plexus of dural vessels that innervate the anterior cranial fossa. 8,9

Yasuda et al raised the question about the origin of Schwann cells in some olfactory groove tumors, and attributed it to the olfactory ensheathing cells (OECs), suggesting, in this way, another entity: olfactory ensheathing cell tumor (OECT). ${ }^{6}$ Despite the similarities in radiological and microscopic assessment, they believed that IHC staining could distinguish OGS from OECT, since Schwann cells, rather than OECs, are positive for Leu7 (cluster of differentiation [CD] 57). ${ }^{10}$ Within these criteria, nine cases of OECT have been proposed in the literature so far. ${ }^{9}$ On the other hand, Bohoun et al reported two cases of mass lesions in the anterior cranial fossa called schwannoma-like tumors, due to the negative IHC staining for Leu7 and positive IHC staining for Schwann/2E, which is a specific marker of Schwann cells. Hence, according to them, this implies a mixed biological nature of both OGSs and OECTs. ${ }^{2}$ Schwann cells and OECs are next to each other by the cribriform plate of the ethmoid bone. Schwann cells cover unmyelinated axons of the nerve fibers up to $0.5 \mathrm{~mm}$ before the olfactory bulb, and OECs, likewise, until two external layers of the olfactory bulb, to facilitate axonal growth. ${ }^{11-13}$

On MRI exams, these lesions appear as a well-circumscribed and encapsulated mass, expressing low to intermediate signal intensity on T1-weighted images and high signal intensity on T2-weighted images. The hyperintensity on T2-weighted images may either be homogeneous or show a target sign with high signal intensity in the periphery of the lesion. 6,8 These pathological findings correspond to a central fibrous tissue and an encircling myxoid tissue. ${ }^{6}$ A differential diagnosis with other tumors in the anterior cranial fossa must include $\mathrm{OECT}^{9}{ }^{9}$ olfactory groove meningioma (OGM), ${ }^{4,9,14-17}$ lowgrade astrocytoma, ${ }^{9,14}$ olfactory neuroblastoma, and metastatic tumors. ${ }^{9,16}$
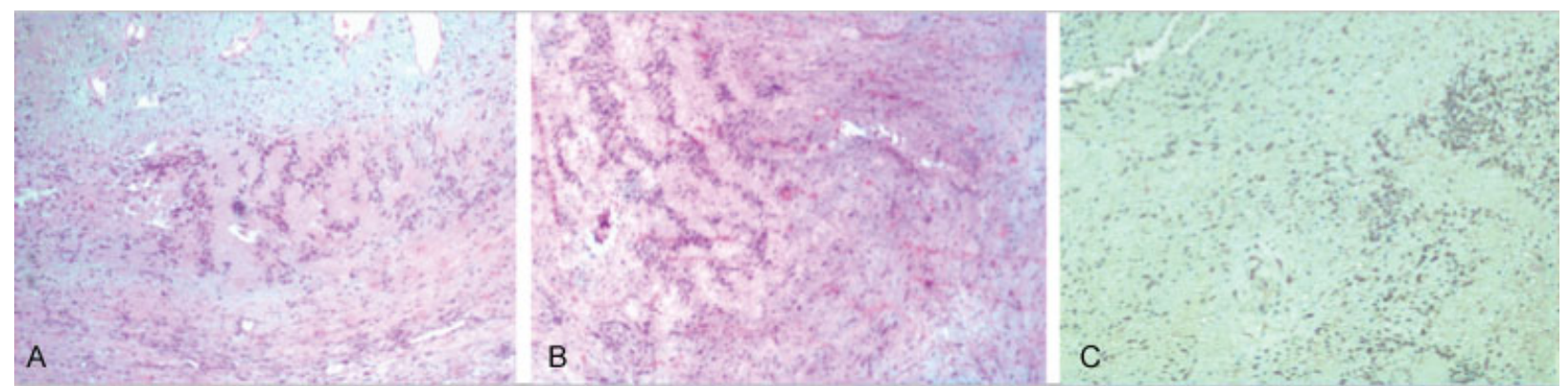

Fig. 2 (A) Photomicrograph showing the hallmarks of schwannoma. Biphasic pattern composed of alternating cellular (Antoni A) and hypo cellular (Antoni B) areas. Cells have twisted or wavy nuclei and indistinct cytoplasmic borders (H\&E stain, magnification 100x). (B) Palisading nuclei form compact rows surrounding fibrillary pink cytoplasm (Verocay bodies). There are pleomorphic and hyperchromatic nuclei, but mitotic figures were not evident (H\&E stain, magnification 100x). (C) Immunohistochemical staining analysis shows that the tumor cells are positive for S-100 protein (magnification 100x). 
A histopathological examination, either in OGS or OECT, reveals a biphasic pattern, consisting of a dense and hypercellular area among a sparse and hypocellular area, called Antoni A and Antoni B areas, respectively. ${ }^{6,8}$ Cells are narrow, elongated and wavy, with tapered ends scattered with spindle-shaped cells (collagen fibers). Often seen, the nuclei of the tumor cells are elongated and arranged regularly to form a palisading aspect, eventually surrounding acellular areas (Verocay bodies). ${ }^{6,8}$ Moreover, neoplastic cells display ill-defined cytoplasm, dense chromatin and frequently degenerative nuclear atypia, but rare mitotic figures. ${ }^{6}$

Since OECTs mimic the clinical, radiological and histopathological features, besides many structural, behavioral and IHC properties of OGSs, ${ }^{6,9,12,14,18}$ the available IHC markers are not able to solve the puzzle regarding the differentiation of these two similar entities. Up to now, both OECs and Schwann cells are positive for S-100 and glial fibrillary acidic protein (GFAP), and negative for EMA. ${ }^{9,12,13}$ Schwann/2E is considered a specific marker of Schwann cells, ${ }^{19}$ and Leu7 may not be considered a tool to discriminate between OECTs and OGSs. ${ }^{2}$

Generalizing the knowledge of surgical strategies from OGMs to OGSs due to their similarities, identical treatment goal and shortage of literature regarding these tumors, it is noticed that the transcranial approach (TCA) is still preferred to the endoscopic endonasal approach (EEA). ${ }^{20}$ Selected cases with clinical or with acceptable postoperative anosmia may benefit from $\mathrm{EEA},{ }^{20,21}$ specially when the size of the tumor is $<4.0 \mathrm{~cm}$ and visual improvement is the main goal. ${ }^{20}$ On the other hand, despite of acquiring a facial scar $^{20,21}$ and more evidence of frontal lobe injury on postoperative MRI assessement, ${ }^{21}$ the TCA is not significantly influenced by tumor size and is superior to the EEA in achieving the virtual cure by gross total resection (GTR) and to avoid cerebral spinal fluid (CSF) leak. ${ }^{20}$ There is no statistical difference between both methods concerning epilepsy, hydrocephalus, infection, stroke, and perioperative mortality rates. ${ }^{20}$

Although subtotal resection is acceptable due to the slowgrowing benign nature of the tumor, ${ }^{4,6}$ complete excision is the treatment of choice. Adjunctive therapy is an exceptional option. ${ }^{8,16}$ In addition, the prognosis of the patient after the total resection of the tumor is favorable. ${ }^{16}$

\section{Conclusion}

Extremely rare tumors, OGSs occur less frequently than any other intracranial nerve schwannoma. Differential diagnosis between OGSs and OECTs is unachievable with the current diagnostic tools. However, the histopathological hallmarks of schwannomas in the anterior cranial fossa after their complete resection showed to be curative. To uncover the genuine origin and pathogenesis of OGSs, more studies are required.

\section{References}

1 Liu Y, Wei M, Yang K, et al. Globose, cystic olfactory ensheathing cell tumor: A case report and literature review. Oncol Lett 2016; 12(05):3981-3986

2 Bohoun CA, Terakawa Y, Goto T. elt al. Schwannoma-like tumor in the anterior cranial fossa immunonegative for Leu7 but immunopositive for Schwann/2E. Neuropathology 2016;•... [ [Epub ahead of print]. Doi: 10.1111/neup.12357

3 Micovic MV, Zivkovic BM, Zivanovic JD, et al. Ancient Olfactory Schwannoma - Case Report and Literature Review. Turk Neurosurg 2016

4 Li YP, Jiang S, Zhou PZ, Ni YB. Solitary olfactory schwannoma without olfactory dysfunction: a new case report and literature review. Neurol Sci 2012;33(01):137-142

5 Figueiredo EG, Soga Y, Amorim RLO, Oliveira AM, Teixeira MJ. The puzzling olfactory groove schwannoma: a systematic review. Skull Base 2011;21(01):31-36

6 Yasuda M, Higuchi O, Takano S, Matsumura A. Olfactory ensheathing cell tumor: a case report. J Neurooncol 2006;76(02):111-113

7 Nascimento LA, Settanni FAP, Filho JF, Sanchez IN, Cavalcante BB, Stávale JN. Isolated schwannoma of the olfactory groove: a case report. Int Arch Otorhinolaryngol 2015;19(01):93-95

8 Choi YS, Sung KS, Song YJ, Kim HD. Olfactory schwannoma-case report-. J Korean Neurosurg Soc 2009;45(02):103-106

9 Wewetzer K, Verdú E, Angelov DN, Navarro X. Olfactory ensheathing glia and Schwann cells: two of a kind? Cell Tissue Res 2002; 309(03):337-345

$10 \mathrm{Mu}$ Q, Gao H, Liu P, et al. Olfactory ensheathing cell tumor: A case report and review of the literature. Oncol Lett 2015;9(05): 2078-2084

11 Figueiredo EG, Gomes MQT, Soga Y, Amorim RL, Rosemberg S, Teixeira MJ. A rare case of olfactory groove schwannoma. Arq Neuropsiquiatr 2009;67(2B):534-535

12 Barnett SC, Chang L. Olfactory ensheathing cells and CNS repair: going solo or in need of a friend? Trends Neurosci 2004;27(01):54-60

13 de Souza HL, Ramos AMO, Ramos CCF, et al. Schwannoma da goteira olfatória: relato de caso. Arq Neuropsiquiatr 2003;61(01): 125-128

14 Kim DY, Yoon PH, Kie JH, Yang KH. The olfactory groove schwannoma attached to the cribriform plate: a case report. Brain Tumor Res Treat 2015;3(01):56-59

15 Carron JD, Singh RVP, Karakla DW, Silverberg M. Solitary schwannoma of the olfactory groove: case report and review of the literature. Skull Base 2002;12(03):163-166

16 Barnett SC. Olfactory ensheathing cells: unique glial cell types? J Neurotrauma 2004;21(04):375-382

17 Lazzari M, Bettini S, Franceschini V. Immunocytochemical characterisation of olfactory ensheathing cells of zebrafish. J Anat 2014;224(02):192-206

18 Ramón-Cueto A, Avila J. Olfactory ensheathing glia: properties and function. Brain Res Bull 1998;46(03):175-187

19 Arai H, Hirato J, Nakazato Y. A novel marker of Schwann cells and myelin of the peripheral nervous system. Pathol Int 1998;48(03): 206-214

20 Shetty SR, Ruiz-Treviño AS, Omay SB, et al. Limitations of the endonasal endoscopic approach in treating olfactory groove meningiomas. A systematic review. Acta Neurochir (Wien) 2017;159(10):1875-1885

21 de Almeida JR, Carvalho F, Vaz Guimaraes Filho F, et al. Comparison of endoscopic endonasal and bifrontal craniotomy approaches for olfactory groove meningiomas: A matched pair analysis of outcomes and frontal lobe changes on MRI. J Clin Neurosci 2015;22 (11):1733-1741 